\title{
Sir Thomas Browne (1605-1682) and life before birth
}

\author{
Peter M Dunn
}

Thomas Browne was born in 1605 . His father was a London merchant about whom little is known. His mother married a second time and Thomas's stepfather, Sit Thomas Dutton, gave him an excellent education, first at Winchester and then at Bradgate Hall, now Pembroke College, Oxford. His undergraduate career was distinguished and he acquired a BA in 1626 , followed by a MA in 1629 . After a visit to Ireland with his stepfather, he went on the grand tour, visiting the famous medical centres of Montpellier, Padua and, finally, Leyden, where he obtained a medical degree in 1633 . The following year he returned to England and then settled at Shibden Hall, near Halifax in Yorkshire, in order to recover his health which had been impaired by shipwreck on the journey home. While recuperating during 1634-5 he occupied himself in writing a book, Religio Medici, which was to make him famous. ${ }^{1} \mathrm{He}$ had not at first intended it for publication but, on an imperfect unauthorised version appearing in 1642, he agreed to the printing of a corrected edition the following year. It at once became and remained a best seller passing through many editions and being translated into Latin, Dutch, French, and German. Browne had a brilliant and cultured mind; he was a scholar who spoke most European languages as well as Latin, Greek and Hebrew, and who had studied and travelled widely. $\mathrm{He}$ was also deeply religious. In the Religion of a Physician he explores and questions in colourful moving phrases the philosophy, prejudices and paradoxes of life. He manages to combine scepticism with humble faith. The following excerpts illustrate the warmth, humour, and humility of the man:

University of Bristol, Southmead Hospital

Correspondence to: Professor P M Dunn, Department of Child Health, Southmead Hospital Southmead Road, Bristol BS10 5NB.

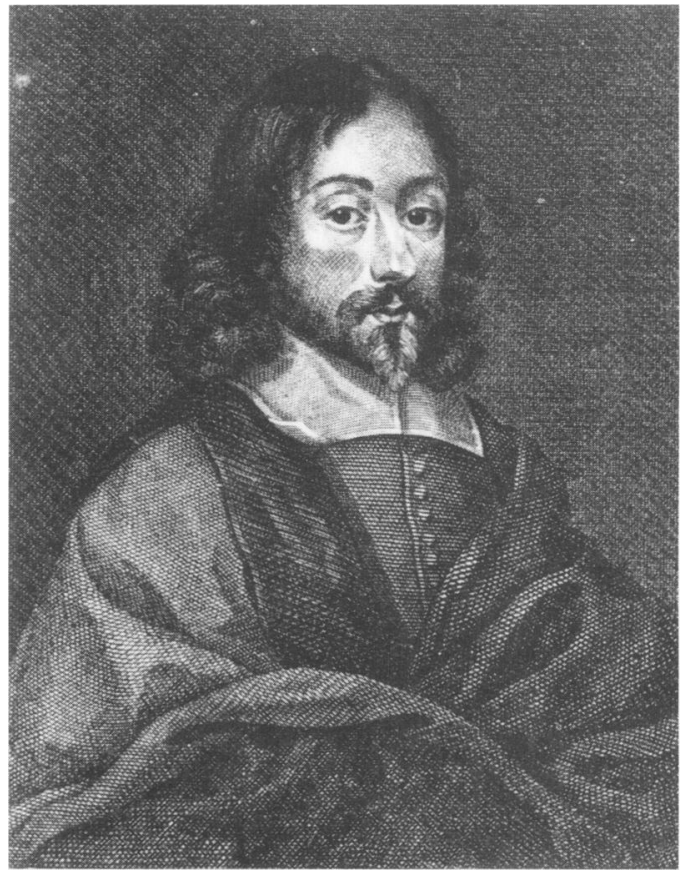

Sir Thomas Browne (1605-1682).

frogs, snails and toadstools; nor at the Jews for locusts and grasshoppers; but being amongst them, make them my common viands, and I find they agree with my stomach as well as theirs. I could digest a salad gathered in a churchyard, as well as in a garden. I cannot start at the presence of a serpent, scorpion, lizard, or salamander: at the sight of a toad or viper, I find in me no desire to take up a stone to destroy them. I feel not in myself those common antipathies that I can discover in others: those national repugnances do not touch me, nor do I behold with prejudice the French, Italian, Spaniard or Dutch: but where I find their actions in balance with my countrymen's, I honour, love, and embrace them in the same degree. I was born in the eighth climate, but seem for to be framed and constellated unto all: I am no plant that will not prosper out of a garden; all places, all airs, make unto me one country; I am in England, every where, and under any meridian; I have been shipwrecked, yet am not enemy with the sea or winds; I can study, play, or sleep in a tempest. In brief, I am averse from nothing: my conscience would give me the lie if I should absolutely detest or hate any essence but the devil;' idio-syncrasy, in diet, humour, air, any thing. I wonder not at the French for their dishes of 


\section{On the multitude}

'If there be any among those common objects of hatred I do contemn and laugh at, it is that great enemy of reason, virtue, and religion, the multitude: that numerous piece of monstrosity, which taken asunder, seem men, and the reasonable creatures of God; but confused together, make but one great beast, and a monstrosity more prodigious than Hydra: it is no breach of charity to call these fools ... Neither in the name of multitude do I only include the base and minor sort of people; there is a rabble even amongst the gentry, a sort of plebeian heads, whose fancy moves with the same wheel as these; men in the same level with mechanics, though their fortunes do somewhat gild their infirmities, and their purses compound for their follies'.

\section{On diversity and God}

'It is the common wonder of all men, how among so many millions of faces there should be none alike. Now contrary, I wonder as much how there should be any: he that shall consider how many thousand several words have been carelessly and without study composed out of twenty-four letters ... Nor doth the similitude of creatures disparage the variety of nature, nor any way confound the works of God. For even in things alike there is diversity; and those that do seem to accord do manifestly disagree. And thus is man like God; for in the same things that we resemble him, we are utterly different from him. There was never anything so like another as in all points to concur: there will ever some reserved difference slip in, to prevent the identity, without which two several things would not be alike, but the same, which is impossible'.

Perhaps Browne's best known passage is that which draws attention to our prenatal existence:

\section{On life before birth}

'Surely we are all out of the computation of our age, and every man is some months elder than he bethinks him; for we live, move, have a being, and are subject to the actions of the elements, and the malice of diseases, in that other world, the truest microcosm, the womb of our mother ... In that obscure world ... our time is short, computed by the moon, yet longer than the days of many creatures that behold the sun; ourselves being not yet without life, sense, and reason; though for the manifestation of its actions, it awaits the opportunity of objects, and seems to live there but in its root and soul of vegetation. Entering afterwards upon the scene of the world, we rise up and become another creature, performing the reasonable actions of man ...'

In 1637 Browne moved to Norwich where, in the words of Osler: 'for 45 years he lived the quiet uneventful life of a student practitioner, absorbed, like a sensible man, in his family, his friends, his studies and his patients'. ${ }^{2}$ Although a staunch royalist, he avoided the controversies of his day. His interests included archaeology and natural history and his house was filled with his collections of medals, books, plants, and birds' eggs. In appearance he was of moderate height and build. His hair was brown and his dress modest. Although always cheerful, he had a natural gravity of manner. When Religio Medici had been written, he was not yet 30 years old and still single. At that time he had reflected on marriage and procreation as follows:

'I was never yet once (married) and commend their resolutions who never marry twice ... I could be content that we might procreate like trees without conjunction, or that there were any way to perpetuate the world without this trivial and vulgar way of coition: it is the foolishest act a wise man commits in all his life; nor is there any thing that will more deject his cooled imagination, when he shall consider what an odd and unworthy piece of folly he hath committed. I speak not in prejudice, nor am averse from that sweet sex, but naturally amorous of all that is beautiful: I can look a whole day with delight upon a handsome picture, though it be but of a horse'.

However, within a few years he had married in 1641, Dorothy, daughter of Edward Mileham of Norfolk and together they had ten children! Edward, the elder of his two sons, followed in his footsteps and eventually became President of the Royal College of Physicians. The younger son served and died with distinction as a sailor in the wars against the Dutch.

The respect in which Browne was held by his colleagues is revealed by the fact that he was elected an Honorary Fellow of the College of Physicians (London) in 1664. A few years later, in 1671, he was knighted by Charles II when he visited Norwich. Sir Thomas died at the age of 77 following a sharp attack of colic on his birthday in 1682 . $\mathrm{He}$ was buried in the Church of St Peter's Mancroft, Norwich.

\footnotetext{
Browne, Sir Thomas. Religio medici. 29th Ed. Gardiner H, ed. London: W Pickering, 1845.

ed. London: Wickering, 1845. as Browne $B M F$ 1905; ii: 993-8.
} 